\title{
THE CHARACTER EDUCATION VALUES IN QUR'ANIC VERSES
}

\author{
Budihardjo; Novi Tazkiyatun Nihayah \\ IAIN Salatiga Jawa Tengah Indonesia \\ E-Mail: budi_stain@yahoo.co.id
}

\begin{abstract}
Character education is one of the main goals of education. Character education is important due to the common believe that there is the degeneration of ethic and moral of the learners, and also due the rise of juvenile delinquency. Then, character education comes to recover it. Character education can be integrated in various aspects, such as in study alQur'ann. The integration between character education and the interpretation of al-Qur'an will make new insight of character education. Moreover, it will be strengthened by the words of Allah. This particular research is intended to reveal whether studies about character education in al-Qur'an will provide a particular kind of character education based on Qur'anic verses, and whether there is any relevance between character education as presented in Qur'anic verses with those presented in curriculum 2013?. To answer these questions, the researcher used descriptive comparative approach, library research as the kind of research, and the use of documentary for collecting the data. This study shows that there are some character education as presented in Qur'anic verses and that there is a relevance between character education values in curriculum 2013 and character education in Qur'anic verses. From the relevance, it is concluded that the character education as presented in Qur'anic verses suggest similar goals as the character education value in curriculum 2013.
\end{abstract}

Keyword: Character Education, Curriculum 2013, Character Education Value, Character Education in Al-Qur'an

Abstrak: Pendidikan karakter merupakan salah satu tujuan utama dari pendidikan itu
sendiri. Pendidikan karakter sangat penting diajarkan kepada peserta didik lantaran adanya
kepercayaan di kalangan masyarakat bahwa dewasa ini telah terjadi degradasi moral dan
kenakalan pada peserta didik. Sehingga hadirnya pendidikan karakter dirasa sangat penting
untukmemulihkan problem diatas. Apalagi, jika pendidikan karakter itu diintegrasikan dengan
nilai-nilai pendidikan yang ada dalam studi al-Qur'an. Untuk itu penelitian ini dimaksudkan
untuk mengungkapkan bagaimana studi tentang pendidikan karakter jika dikaitkan dalam
perspektif al-Qur'an?, dan apakah ada relevansi antara pendidikan karakter seperti yang
disajikan dalam ayat-ayat al-Qur'an dengan yang disajikan dalam kurikulum 2013?. Untuk
menjawab pertanyaan ini, peneliti menggunakan pendekatan komparatif deskriptif, penelitian
kepustakaan sebagai jenis penelitian, dan penggunaan dokumenter untuk mengumpulkan
data. Studi ini menunjukkan bahwa ada beberapa pendidikan karakter seperti yang disajikan
dalam ayat-ayat al-Quran, dan ditemukan ada relevansi antara nilai pendidikan karakter dalam
kurikulum 2013 dan pendidikan karakter dalam ayat-ayat al-Qur'an. Begitu juga ditemukan
bahwa nilai-nilai pendidikan karakter sebagaimana yang terdapat dalam ayat-ayat al-Qur'an,
ternyata selaras dengan nilai-nilai pendidikan karakter yang ada dalam kurikulum 2013 .

Kata kunci: Pendidikan Karakter, Kurikulum 2013, Nilai Pendidikan Karakter, Pendidikan Karakter dalam Al-Qur'an. 


\section{INTRODUCTION}

Islam is the religion for all human, the rahmatan-lil'alamin. All tenets of Islam are based on the eternal unchangeable divine revelation. This divine revelation from Allah is embodied in al-Qur'ān. The holy al-Qur'ān consists of tenet, command and direction of lives and one of them is about education. Education is the important point that has to be carried out by Muslim, because education is obligation that has similar encouragement like praying, fasting and others obligations of religion ${ }^{1}$. Rasulullah PBUH said:

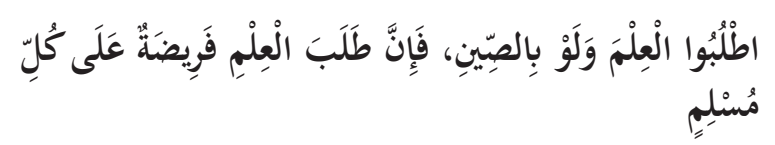

Meaning: Seek the knowledge until China, Indeed seeking knowledge is the duty for Moslems (H.R. Ibnu Majjah, 1997: No.224)

Education based on UU No. 20 Years 2003 about SISDIKNAS (National System of Education) is directed to developing student's potential to be faithful human, obidient to Allah, having noble character, healthy, knowledgeable, clever, creative, independent, and democratic as well as responsible citizen (section 3 ). It has been widely known that lots citizen do not have noble character as they commit the corruption, drug abuse, and violences. They are also very consumptive, irresponsible, that contradict the purpose of national education.

Education is an institutional mechanism that will accelerate nation's character building and a medium to achieve three principals in nation's character building, those are: First, education as a medium to re-activate noble characters of Indonesia; Second, education as a medium of acceleration of character development of nation and the mobilization of domestic potential to upgrade competitiveness of

1 Mustaqim, Abdul. Menjadi Orang tua Bijak: Solusi Kreatif Menangani Berbagai Masalah Pada Anak. Bandung: Mizan Media Utama (MMU). 2005. p.13 the nation; Third, education as medium to internalize two aspects i.e. the re-activation of the glory of our ancestors' culture, innovative and competitive character that are concerted in all national life and government principles. ${ }^{2}$

Character education, appear as the weapon against the criticalities of moral. Educational character is a systematic educational program to help student in understanding the values of human behavior to their God, their own being, their humanity, their environment, and their nation that should be manifested in their thinking, attitude, feeling, words, attitudes and behaviours. It shall be based on religious norms, laws, politeness, culture, and traditions. ${ }^{3}$

There are $18^{\text {th }}$ character listed on character education in curricullum 2013. Those are: religious, honest, tolerant, discipline, work hard, creative, independent, democratic, inquiring, nationalism, achievement appreciate, friendliness, peace loving, delight in reading, environmental concern, social concern and responsible. Those eighteen characters are expected to upgrade human resources of our nation, in order to achieve educational purposes optimally.

\section{DISCUSSION}

Dealing with the important of character building, Al-Qur'ān is the most precise source, it also teachs character building for the nation. Al-Qur'ān is an everlasting islamic miracle, which the validity of it proven by the progress of knowledge. ${ }^{4}$ So, in this article the researcher will explain about the character education of curriculum 2013 based on the Qur'anic verses.

2 Muslich, Masnur. Pendidikan Karakter: Menjawab Tantangan Krisis Multidimensional. Jakarta: Bumi Aksara. 2011.p.3

3 Listyarti, Retno. Pendidikan Karakter: dalam Metode Aktif, Inovatif, \& Kreatif. Yogyakarta: Erlangga Group. 2012. P.4

4 Al-Qaththan, Manna'. Pengantar Studi Ilmu AlQur'an. Jakarta: Pustaka Al- Kautsar. 2004. pp.3 


\section{Explanation}

a. Definition of Character Education

In order to comprehend the meaning of character education it should be understood the definition of both "education" and "character". The word "Education" derived from Latin "Educere" that means to lead forth. Furthermore, terminologically education is the process of providing knowledge, skill, competence or the use of desirable qualities of behaviour or character of being, provided by a formal course of study, instruction or training (Webster, 1981: 723). The Encyclopedia International defines education as an increase of skill or development of knowledge and understanding as a result of training, study, or experience. ${ }^{5}$ Education goes in all societies for, in order to survive, a society must pass on basic skills, information, and beliefs from one generation to the next.

Etymologically the term "character" comes from Greek "charassein" "kharax" which means tools for making or to Engrave. Like the carvings that are attached to the objects are carved, the character is also attached to the individual, because of it character is defined moral or mental nature, mental or moral qualities that make one person, race etc different from others. ${ }^{6}$

According to Imam Ghozali, the term character is closer to the term of moral, i.e. the human spontaneity in the act, or acts that are fused in a man who does not need to think anymore when the attitude is appear (Koesoma, 2011: $8)^{7}$

Character is like carving out, and then the forming of character can be described as a man carves on a stone or hard surfaces metal. Character is

$5 \quad$ Encyclopedia International Vol. 5. New York: Grolier Incorporated. 1973. Pp.247

6 Hornby, A.S. Oxford Advanced Learner's Dictionary Of Current English. Oxford: Oxford University Press. 1974. Pp. 140

7 Koesoema, Doni. Pendidikan Karakter: Untuh dan Menyeluruh. Yogyakarta: Kanisius. 2012.pp.8 behavior, moral, personality of someone that formed from the internalization of various virtues and underline perspective, thinking, attitudes, and the way people act. The virtue consists of a number of values, morals, and norm such as honesty, courage act, trustworthiness, and respect to others.

Character education is an education system with invest values accordance with the nation's culture and knowledge aspects, feels of affection, and actions, both a g ainst Almighty God either for themse 1 ves, the communities and the nation. ${ }^{8}$

Ki Haj a $r$ Devantoro defines character education as a planned effort to make students know, care about and intern a lize the values, so that students behave as a perfect man. Accordingly, the go a 1 of character education is to improve the quality implementation and ou tcomes of education in schools throug $h$ the formation of character of stu d ents as a whole, integrated, and ba 1 anced, in accorance with the competency standards. ${ }^{9}$

David E lkind and Freddy Sweet Ph.D. interpret the character education as the deliberate effort to help people unders tand, care about, and act upon core e t hical values. ${ }^{10}$ It is strongly associ a ted with the term "character", that mapped directly in our minds to the future of our students, where they can assess "what is right, have deep concern about $\mathrm{w}$ hat is right, and then do what they believe to be right, even in the face of pressure from without and temptation from within".

From the explanation above, it can be concluded that character education is an education system that is performed by ins $\mathrm{t}$ illing noble values, morals,

8 Afandi, Rifki. Integrasi Pendidikan Karakter dalam Pembelajaran IPS di Sekolah. Pedagogia vol. 1, No. 1, Desember 2011. Pp. 88

9 Hary a nto. Pendidikan Karakter Menurut Ki Hajar Dewantoro.Pdf: UNY. Pp.4

10 Syahroni. Konsep Pendidikan Karakter. PDF [online]. Availab le at http://lampung.kemenag.go.id accessed February $4^{\text {th }} 2014$ at 11.20 . pp.3 
ethics and culture of any material that can help individuals learn to live and work together as a family, society and nation. So learning system is not only emphasize the cognitive aspects, but also psychomotor and affective aims to make qualified individuals.

b. Character Education Values

The values in the educational development of the nation's culture and character ac c ording to the Guideline Development $C$ ulture and Character Education $\mathrm{Nat}$ ion identified from the following sources: ${ }^{11}$

c. Religion

Religion in Arabic is " الدين " which comes from the word دين compiled by the letter da'(د), ya'(ي), nun(ن) it constitutes and derives word such as الدين word (religion) , الدين (Debt), (ادانة (Conviction), مدن مدن (Cities) , (to civilize) , تمدن (cilivization). ${ }^{13}$ From these explanations in Arabic literatur, religion is very closely related to society and civilization. Friedrich Schleiermacher defines that religion is "feeling of absolute dependence " - as contrasted to other absolute, relative feeling of dependence. ${ }^{14}$

Therefore the life of the individual, society, and nation is always based on religious teachings and beliefs. Politically life of the state is based on values derived from religion. On the basis of these considerations, the values of character education should be based on the values and principles derived from religion.

d. Pancasila

The Republic of Indonesia upheld by the principles of nationhood and statehood called Pancasila. Pancasila contained in the 1945 Constitution and further elaborated in the articles contained in the 1945 Constitution.

11 Suyadi. Mencegah Bahaya Penyalahgunaan Narkoba Melalui Pendidikan Budaya dan Karakter Bangsa. Yogyakarta: ANDI. 2013. pp.37

12 Maqoyisul Lughoh

13 Zakiyyudin. Definition of Religion.ppt. STAIN. 2011. P. 2

14 Eliade, Mircea. The Encyclopedia of Religion Vol. 11. New York: Macmillan Library Reference. 1995.pp.283
That is, the value contained in Pancasila become the values that govern the political, legal, economic, social, cultural, and artistic set fo $r$ th in the articles of the 1945 Constit $u$ tion. Character education aims to prepare students to be better citizens, who have the ability, willingness, and a p ply the values of Pancasila in their lives as citizens.

e. Culture

Culture is human development of the human powers ; development of the body, mind and spirit by training and experience. ${ }^{15}$ Culture is a truth that no man is living in a society without cultural values of the community recognized. The cult u ral values become the basis of the i $\mathrm{n}$ terpretation of the concept and mean ing of the co m munication among the community members. Such an impor $t$ ant position in the cultural life, culture become values sources of character education.

f.. The Objective of National Education

National education goals reflect the quality of every Indonesian citizen, was developed by various educational units at various levels and lines. ${ }^{16}$ In the natio nal education goals there are different grades of humanity that must be inte rnalized by Indonesian citizens. Therefore, the goal of national education is the $\mathrm{m}$ ost operational source in the develop $\mathrm{m}$ ent of character education compared to the three sources mentioned earlier.

Based on the four values sources above, then the identified 18 values that have been developed in the nation's culture and character education by the Ministry of Education and Culture are as follow ${ }^{17}$ :

15 Hornby, A.S. Oxford Advanced Learner's Dictionary Of Current English. Oxford: Oxford University Press. 1974. pp. 210

16 Afandi, Rifki. Integrasi Pendidikan Karakter dalam Pembelajaran IPS di Sekolah. Pedagogia vol. 1, No. 1, Desember 2011. Pp.91

17 Listyarti, Retno. Pendidikan Karakter: dalam Metode Aktif, Inovatif, \& Kreatif. Yogyakarta: Erlangga Group. 2012. Pp.5-8 


\begin{tabular}{|c|c|c|}
\hline No. & Values & Descriptions \\
\hline a. & Religious & $\begin{array}{l}\text { Attitudes and behavior of the obedient in carrying out their religion, } \\
\text { tolerant implementation of worship of other religions, and live in } \\
\text { harmony with other religions. }\end{array}$ \\
\hline b. & Honest & $\begin{array}{l}\text { Behavior based on an attempt to make himself as one who can always be } \\
\text { trusted in words, actions, and employment. }\end{array}$ \\
\hline c. & Tolerance & $\begin{array}{l}\text { Attitudes and actions of respect to the differences of religion, race, } \\
\text { ethnicity, opinions, attitudes and actions of others who are different from } \\
\text { themselves. }\end{array}$ \\
\hline d. & Discipline & $\begin{array}{l}\text { Measures indicating orderly and obedient behavior on various rules and } \\
\text { regulations. }\end{array}$ \\
\hline e. & Hard work & $\begin{array}{l}\text { The behavior that indicate an earnest effort to overcome barriers of } \\
\text { learning and completing assignments and tasks as well as possible. }\end{array}$ \\
\hline f. & Creative & $\begin{array}{l}\text { Think and do something to produces new ways or results based on what } \\
\text { students have. }\end{array}$ \\
\hline g. & Independence & Uneasy attitude and behavior to depend on other in completing the task. \\
\hline h. & Democratic & $\begin{array}{l}\text { The way of thing and behave that balancing between rights and obligations } \\
\text { of oneself and others. }\end{array}$ \\
\hline i. & Curiosity & $\begin{array}{l}\text { Attitudes and actions are resulted from the deeper and wider questioning } \\
\text { on what students have learnt, seen, and heard. }\end{array}$ \\
\hline j. & Spirit of Nationality & $\begin{array}{l}\text { The way of think, act, and insight, that set the needs of the nation beyond } \\
\text { the self-interest and group interest. }\end{array}$ \\
\hline k. & Nationalism & $\begin{array}{l}\text { The way of think, and act that exhibit loyalty, care, and high appreciation } \\
\text { of language, physical environment, social, cultural, economic, and } \\
\text { national policy. }\end{array}$ \\
\hline 1. & $\begin{array}{l}\mathrm{R} \text { e w a } \mathrm{r} \text { d i n g } \\
\text { Achievement }\end{array}$ & $\begin{array}{l}\text { Attitudes and actions that encourage students to produce something } \\
\text { useful for society, and recognize the success of others. }\end{array}$ \\
\hline $\mathrm{m}$. & Friendliness & $\begin{array}{l}\text { Acts that show enthusiasm to mingle, make friend, and cooperate with } \\
\text { other students. }\end{array}$ \\
\hline n. & Peace Loving & $\begin{array}{l}\text { Attitudes, words and actions that make other people feel happy and safe } \\
\text { over one's presence. }\end{array}$ \\
\hline o. & Reading Interest & $\begin{array}{l}\text { Sparing time habit to read the various reading materials that provide } \\
\text { virtue for students. }\end{array}$ \\
\hline p. & Social Concern & $\begin{array}{l}\text { Attitudes and actions always want to help others who are in need in the } \\
\text { communities. }\end{array}$ \\
\hline q. & $\begin{array}{l}\text { Environmenta } 1 \\
\text { Concern }\end{array}$ & $\begin{array}{l}\text { Prevent damage action to the surrounding natural environment, and } \\
\text { develop to compensate the occurred damage. }\end{array}$ \\
\hline r. & Responsible & $\begin{array}{l}\text { The attitude and behavioral of students to carry out duties and obligations } \\
\text { that they have, for themselves, for the society, the environment, the state, } \\
\text { and the Almighty God. }\end{array}$ \\
\hline
\end{tabular}

\section{Character Education Values in Qur'anic} Verses

a. Religiousity

Religiosity is the noun form of religious, means behaving a strong belief in a religion. ${ }^{18}$ In the curriculum 2013 religiosity is attitudes and behavior of the obedient in carrying out their religion, tolerant implementation of worship of other religions, and live in harmony with other religions. According

18 Oxford Wordpower. New York: Oxford University Press. 2006. Pp.647 to Rokeach and Bank, religiosity is an attitude or consciousness emerged based on the belief of religion. ${ }^{19}$

Religiosity is not identical with religion. Religion refers to the institutional, the worship of God, the formal aspect, juridical, regulations and laws. Religiosity tend to look at the inside of heart. Then, the understanding

19 Sahlan, Asmaun. Mewujudkan Budaya Religius di Sekolah: Upaya Mengembangkan PAI dari Teori ke Aksi. Malang: UIN- Maliki Press. 2009. Pp.66 
of religiosity is broader than religion. ${ }^{20}$

Religious in curriculum 2013 means an attitudes and behavior of the obedient in carrying out their religion, tolerant implementation of worship of other religions, and live in harmony with other religions.

Those explanations are in line with the words of Allah SWT:

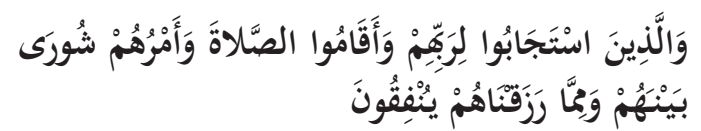

Meaning: "Those who hearken to their Lord, and establish regular Prayer; who (conduct) their affairs by mutual Consultation; who spend out of what We bestow on them for Sustenance" (Q.S. asy-Syūrā: 38)

The verse above explains that the people who will receive the reward of the Hereafter are those who categorize in; faith, rely on God in all matters, avoiding sin, and be able to control anger . ${ }^{21}$

All of the categories described in that verse shall not owned by someone who does not have an attitude in religiosity. Because according to Qurais Shihab, this verse describes the neighbour thing adorn our selves, and those jewelry was prepared for people who are included in categories above. ${ }^{22}$

Then, the value of religiosity is considered necessary investment in education as internal guidelines within each individual, in order to direct all acts. Although sparkling modern world offers extraordinary things, they are still controlled by the value.

The religious activities in school have been implemented through practicing prayer together between teacher and student, the obligation to pray Friday prayer for every student

20 Ibid.

21 Al- Maraghi, Ahmad Mustofa. Jilid.,25. Tafsir AlMaraghi. Semarang: CV. Toha Putra. 1974. Pp.29

22 Shihab, M. Quraish. Vol. 12. Tafsir Al-Misbah: Pesan, Kesan dan Keserasian al- Qur'an. Ciputat: Lentera Hati. 2003. Pp.511 (man and woman), and also supporting many religious activities of various religious organization in school etc.

b. Honesty

To be honest is not to tell lies, not to cheat or to steal. Straightforwardly, honesty is the quality of being honest. ${ }^{23}$ In Curriculum 2013 honesty is a behavior based on an attempt to make himself as one who can always be trusted in words, actions, and employment.

The meaning of honesty suggests human behavior both in words and in deeds. Then, to know someone is honest or not, one shall observe the behaviors and habits of that person within the daily life. The necessity of inculcating honest behavior in every child is the interest of every parent, teacher and the coomunities. Allah says:

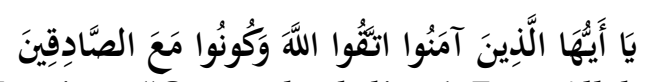
Meaning: "O ye who believe! Fear Allah and be with those who are true (in word and deed)." (Q.S. at-Taubat: 119).

The verse above explains, about the right information is appropriate with the condition, reality, and mutual accord between acts and believes. ${ }^{24}$ Honesty has similar basic value as righteousness, and then honesty has same elements as the righteousness.

c. Tolerance

Tolerance is willingness to allow people to be, to do, to say, or believe what they want without criticizing them..$^{25}$ In the character education curriculum, tolerance is attitudes and actions of respect to the differences of religion, race, ethnicity, opinions, attitudes and actions of others who are different from themselves.

23 Hornby, A.S. Oxford Advanced Learner's Dictionary Of Current English. Oxford: Oxford University Press. 1974. Pp.409

24 Shihab, M. Quraish. Vol.5. Tafsir Al-Misbah: Pesan, Kesan dan Keserasian al- Qur'an. Ciputat: Lentera Hati. 2002. Pp.682

25 Longman. LONGMAN Dictionary of Contemporary English. UK: Longman. 1978. Pp.1674 
Tolerance is an appropriate behaviour in facing the heterogenity of life to create the harmonious life under the togetherness. ${ }^{26} \quad$ Etymologically tolerance is an attitude of allow and respect each other relating the others beliefs without requiring approval. ${ }^{27}$ Generally, tolerance is defined as giving freedom to his fellow man or citizens to practice their faith or organize their life and determine their fate, while not in contradiction with the requirements of law and peace in society.

In social and political aspect, tolerance is an attitude of allowing people to have a various belief, accepting the statement as a recognition and respect for human rights. Tolerance should be based on spaciousness to others with regard to the principles themselves and respecting other people.

Actually, tolerance born from the Islamic character, as described in the Qur'an that support the ethical difference and tolerance. The Qur'an not only expects, but also accepts difference and diversity in the community. This is in accordance with the word of Allah:

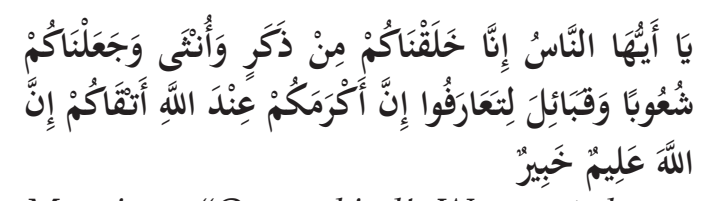

Meaning: "O mankind! We created you from a single (pair) of a male and a female, and made you into nations and tribes, that ye may know each other (not that ye may despise (each other). Verily the most honoured of you in the sight of Allah is (he who is) the most righteous of you. And Allah has full knowledge and is well acquainted (with all things)" (Q.S. al-Hujurāt: 13).

26 Juwariyah. Pendidikan Moral dalam Puisi Imam Syafii dan Ahmad Syuqi. Yogyakarta: Sukses Offset. 2008 pp. 250

27 Hasyim, Umar. Toleransi dan Kemerdekaan Beragama dalam Islam Sebagai Dasar Menuju Dialog dan Kerukunan Antar Agama. Surabaya: PT. Bina Ilmu. 1979. Pp.22
The verse indicates the human obedience to ignore the essential differences between the groups that split them one another, because everyone are pillar of a large family. It is also provides an overview of the basic principles of human relations. The stronger introduction of one side to others increases the opportunities for mutual benefit. ${ }^{28}$

d. Discipline

Discipline is a way of training someone so that they learn to control their behavior and obey rules, which involve punishing them if they do not obey rules. ${ }^{29}$ In curriculum 2013, Discipline was define as measures indicating orderly and obedient behavior on various rules and regulations.

Self-discipline is the main aspects of education in the family carried by parents. Because they are the responsible one in laying the foundation of life for their children. The efforts of parents and educators will be achieved, when children has been able to control their own behavior with moral values. If a child has been able to discipline themselves, it means that they has the ability to anticipate, accommodate, and control themselves in facing the globalization. ${ }^{30}$

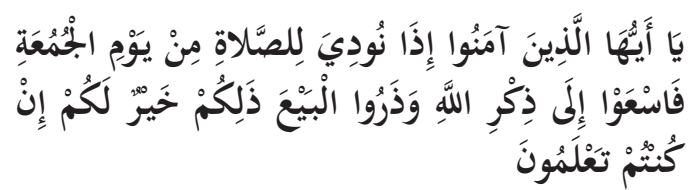

Meaning: "O ye who believe! When the call is proclaimed to prayer on Friday (the Day of Assembly), hasten earnestly to the Remembrance of Allah, and leave off business (and traffic): That is best for you if ye but knew!" (Q.S. al-Jumu'ah: 9).

28 Shihab, M. Quraish. Vol. 13. Tafsir Al-Misbah: Pesan, Kesan dan Keserasian al- Qur'an. Ciputat: Lentera Hati. 2003. Pp. 262

29 Longman. LONGMAN Dictionary of Contemporary English. UK: Longman. 1978. Pp.452

30 Shohib, Moh. Pola Asuh Orang Tua: Untuk Membantu Anak Mengembangkan Disiplin Diri. Jakarta: PT. RINEKA CIPTA. 1998. Pp. 6 
This verse explains the invitation to the believer to immediately fulfill the divine call, if the call "adzan" has been called. ${ }^{31}$ Hasten in the verse represented the word "فاسعوا" indicates a command to be disciplined. When it has scheduled an important plan, then leave other things outside the plan. As told to leave all matters when the call to prayer has called.

\section{e. Hard Working}

Hard work is working seriously and with a lot of effort. ${ }^{32}$ In the Curriculum 2013 hard work is behavior that indicate an earnest effort to overcome barriers of learning and completing assignments and tasks as well as possible.

Hard work means trying hard to get the maximum results. (In hadith the Prophet PBUH said:

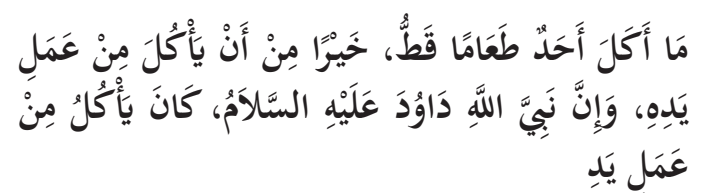

"There is no single food that is better eaten than his own sweat foods. Verily Prophet Dawud eating from the results of his own sweat. "(HR Sahih Bukhāri, 1966, No. 2072). ${ }^{33}$

As in the following the words of Allah:

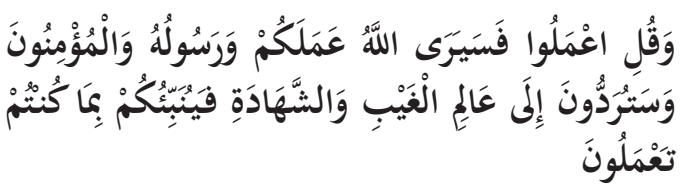

Meaning: "And say: "Work (righteousness): Soon will Allah observe your work, and His Messenger, and the Believers: Soon will ye be brought back to the knower of what is hidden and what is open: then will He show you the truth of all that ye did" (Q.S. atTaubat: 105).

31 Shihab, M. Quraish. Vol. 14. Tafsir Al-Misbah: Pesan, Kesan dan Keserasian al- Qur'an. Ciputat: Lentera Hati. 2003. Pp. 231

32 Longman. LONGMAN Dictionary of Contemporary English. UK: Longman. 1978. Pp.736

33 Shohih Bukhāri. “1966. ،باب الرجل و عمله بيده.No. 2072
This verse is an explanation of the command executing pious charity, having previously described about forgiveness. This is relevant because although repentance has been obtained, but previous time has been filled with iniquity, and would not be restored again. Relating to the hard work, this surah analogy in terms of forgiveness. Although God gives opportunity to everyone to repent, but we are not allowed to relax without doing pious deeds. Although we have opened the doors of repentance, we still have to do pious charity.

The verse commanded Prophet Muhammad to convey to his people that: do work because of Allah through variety of charities, both to our own self and the general public. ${ }^{34}$ God will judge their deeds then reward them.

f. Creativity

Creativity is the ability to use your imagination to produce or use new ideas, make thing etc. ${ }^{35}$ According to Psychologist creativity is an ability to make new combination based on available data, information, and elements. Based on specialist said that creativity is willingness to create something new. ${ }^{36}$

Creativity belongs to everyone, even though each individual was different. In the world of education, developing creativity is very important, because without creativity education will be merely knowledge transferring process whereas ideal education shall include three aspects; cognitive, affective and psychomotoric.

Understanding the talents of children and develop their creativity is very important, if not, the talent and

34 Shihab, M. Quraish. Vol. 1. Tafsir Al-Misbah: Pesan, Kesan dan Keserasian al- Qur'an. Ciputat: Lentera Hati. 2012. Pp. 588

35 Longman. LONGMAN Dictionary of Contemporary English. UK: Longman. 1978. Pp.373

36 Mustaqim, Abdul. Menjadi Orang tua Bijak: Solusi Kreatif Menangani Berbagai Masalah Pada Anak. Bandung: Mizan Media Utama (MMU). 2005. Pp.117 
potential will not be developed properly. The prophet Muhammad commanded parents to train their children and teach archery, sewing, swimming, and so on. Therefore, it could be from the process of the exercise, the talent and creativity will flourish. ${ }^{37}$

Allah SWT said:

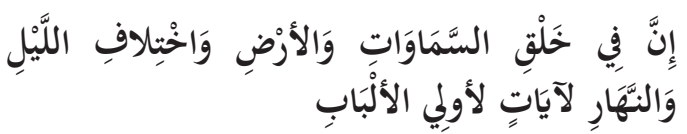

Meaning: "Behold! in the creation of the heavens and the earth, and the alternation of night and day, there are indeed Signs for men of understanding" (Q.S. 'Ali Imrān: 190).

The verse above describes the creation of the heavens and the earth prepared by God, and the command to think about it. ${ }^{38}$ Those illustrations shows that Allah was created the universe and its contents as the object of thinking for those who want to think. And who has willing to pay attention to the universe is called Ulul albab.

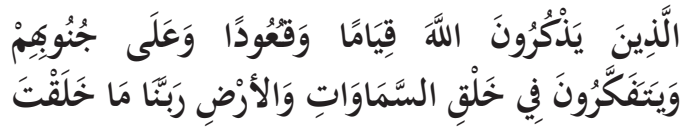

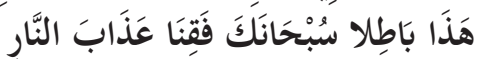

Meaning: "Men who celebrate the praises of Allah, standing, sitting, and lying down on their sides, and contemplate the (wonders of) creation in the heavens and the earth, (With the thought): "Our Lord! not for naught Hast Thou created (all) this! Glory to Thee! Give us salvation from the penalty of the Fire." (Q.S. 'Ali Imrān: 191).

Ulul Albab is they who have a high sense of curiosity to his surroundings. In the verse above described characteristics of Ulul albab, there are; a. Always remember God in all circumstances, b. Thinking about the creation of the

$37 \quad$ Ibid.pp. 115

38 Shihab, M. Quraish. Vol. 2. Tafsir Al-Misbah: Pesan, Kesan dan Keserasian al- Qur'an. Ciputat: Lentera Hati. 2000. Pp. 290 heavens and the earth. ${ }^{39}$

The characteristics of Ulul albab equal with the characteristics of creativity affective that has a high sense of curiosity and always creates innovation of new things encountered. These characteristics refer to the creative attitude which always want to make a new ways and discovery of what is owned.

g. Independence

Independency is confident and able to do things by yourself in your own way, without needing help from other people. ${ }^{40}$ In the character education curriculum, independency is uneasy attitude and behavior to depend on other in completing the task.

An expert wisdom says: "If the child is raised in comforting, he will learn to be selfish". ${ }^{41}$ As we know that the difference of indulgent and loving is thin, then it should be limited in loving so that children do not fall into indulgence. These limitation can be done by embedding independent attitude.

With independent personality, a learner can be expected to have: the principle of life, solid personality, optimistic mental, positive thinking, responsible, and able to put himself in the right position. The positive benefits of independent attitude same as contained in the Word of Allah:

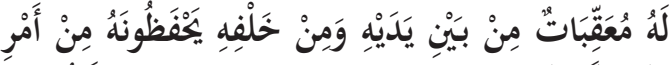

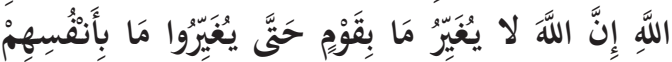

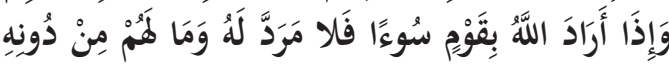

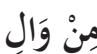

Meaning: "For each (such person) there are (angels) in succession, before and behind him: They guard him by command of Allah.

39 Shihab, M. Quraish. Vol. 2. Tafsir Al-Misbah: Pesan, Kesan dan Keserasian al- Qur'an. Ciputat: Lentera Hati. 2000. Pp. 293

40 Longman. LONGMAN Dictionary of Contemporary English. UK: Longman. 1978. Pp.818

41 Mustaqim, Abdul. Menjadi Orang tua Bijak: Solusi Kreatif Menangani Berbagai Masalah Pada Anak. Bandung: Mizan Media Utama (MMU). 2005. Pp.128 
Verily never will Allah change the condition of a people until they change what is within themselves. But when (once) Allah willeth a people's punishment, there can be no turning it back, nor will they find, besides Him, any to protect." (Q.S. ar-Ra'd: 11).

The verse above explains that the social changes of a people will not be done by Allah, before they do step first. ${ }^{42}$ This verse shows that Allah teaches independence to His servant, even though Allah is the Powerful one, Allah still provide an opportunity to people to try it first.

This verse also explaines that in man there is an "iradah" (press and willpower). Iradah is equipped to human beings so that humans are not entirely surrender to the will of destiny. Those who do not want to use their iradah, are those who are not independent and rely on others. Allah does not promise anything for those who do not want to try.

In the world of education, independence needs to be encouraged so that learners accustomed to do the task without the help of others. In addition, the independence will make personality grow strong and not easily influenced in everything around him.

h. Democratic

Democratic is having or supporting equality for all member. ${ }^{43}$ Democratic in the curriculum 2013 is the way to think, behave and act the same rights and obligations judging him and others. This definition of democracy directs learners to understand the equality. There are no differences between people that create the social gap.

According to Abdurrahman Wahid, the value of democracy is not only a consultative, but also other basic values

42 Shihab, M. Quraish. Vol. 6. Tafsir Al-Misbah: Pesan, Kesan dan Keserasian al- Qur'an. Ciputat: Lentera Hati. 2002. Pp. 560

43 Oxford Wordpower. New York: Oxford University Press. 2006. Pp.208 such as: ${ }^{44}$

1) Freedom

Individual freedom in the presence of power state or balance between the individual rights with the collective rights of the community.

2) Justice

Is a foundation of democracy, it means opening up opportunities for everyone, and the independence of individuals for implementing their neccesities without violating the rights of others.

3. Consultative (Common Agreement)

The ways to preserve freedom and fight for justice. From these three basic values of democracy, freedom is the most inclined underlying intent of democratic values promoted in 2013. Where equality of rights and obligations of human beings must be upheld and applied in social life. However, freedom will not run optimally without the other values, justice and consultative.

The justice value explains that every human being has the same rights and obligations, and each individual has the same opportunity to go ahead. However, it is restricted to not interfere with the rights of others. Then the control of freedom and justice, embodied in the value of consultative. In the sense that this value aims to maintain the fight for freedom and justice.

It is in accordance with the word of Allah SWT:
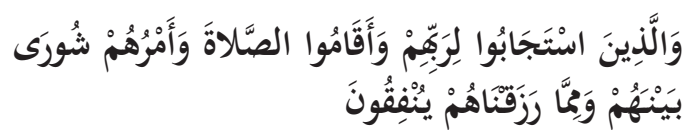

44 Wahid, Abdurrahman. Dialog Pearadaban untuk Toleransi dan Perdamaian. Jakarta: PT Gramedia Pustaka Utama. 2010. Pp. 162 
Meaning: "Those who hearken to their Lord, and establish regular Prayer; who (conduct) their affairs by mutual Consultation; who spend out of what We bestow on them for Sustenance" (Q.S. asy-Syūrā: 38).

The verse above explains that all matters relating to the society, it should be decided by consultation between them. No authoritarian to impose his opinion. ${ }^{45}$ Consultation (common agreement) has taught by Prophet Muhammad PBUH to his friend since the war. When they deal with some important matters, then they carry parley between them, so that the matter can be discussed and studied together. ${ }^{46}$ i. Curiousity

Curiosity is the desire to learn about something or to know something. ${ }^{47}$ Curiosity is an emotion related to the curious behavior such as; exploration, investigation, and learning, evident by observation in human and many animal species. This term can be used to show the behavior itself caused by the emotion of curiosity. As an emotional, curiosity in an encouragement to know new things. Curiosity is the main driving force behind scientific research and other disciplines of human study.

In the world of human education, human curiosity developed along with the development of human life and the time in which they live. The historic period of human life from hunting and farming are moving from one place to another, then increases to farmers and ranchers to finally settle in their prefered location. These developments, discuss about the curiosity that need to enter in the world of education. Human curiosity will never run out, when innovation appear, it would appear the

45 Shihab, M. Quraish. Vol. 12. Tafsir Al-Misbah: Pesan, Kesan dan Keserasian al- Qur'an. Ciputat: Lentera Hati. 2003. Pp. 511

46 Al- Maraghi, Ahmad Mustofa. Jilid.25. Tafsir AlMaraghi. Semarang: CV. Toha Putra. 1974. Pp. 94

47 Longman. LONGMAN Dictionary of Contemporary English. UK: Longman. 1978. Pp.388 other curiosity. This is similar to the education that develop over the times.

According to Donald Latumahina in (Latumahina, 2013: 3) there are four benefits of curiosity, there are: ${ }^{48}$

1) It makes your mind active instead of passive

Curious people always ask questions and search for answers in their minds. Their minds are always active. Since the mind is like a muscle which becomes stronger through continual exercise, the mental exercise caused by curiosity makes our mind stronger and stronger.

2) It makes your mind observant of new ideas

When you are curious about something, your mind expects and anticipates new ideas related to it. When the ideas come they will soon be recognized. Without curiosity, the ideas may pass right in front of you and yet you miss them because your mind is not prepared to recognize them.

3) It opens up new worlds and possibilities

By being curious you will be able to see new worlds and possibilities which are normally not visible. They are hidden behind the surface of normal life, and it takes a curious mind to look beneath the surface and discover these new worlds and possibilities.

4) It brings excitement into your life

The life of curious people is far from boring. It's neither dull nor routine. There are always new things that attract their

48 Latumahina, Donald. 4 Reasons Why Curiosity is Important and How to Develop It [online]. Available at (http://www.lifehack.org) accessed 6 Agustus 2014 at 10.56 
attention, there are always new 'toys' to play with. Instead of being bored, curious people have an adventurous life.

From the benefits above, suggests that people who have more curiousity can interpret the essential of lives in this world. They will pay attention to everything they see, hear or feel. As in the words of Allah:

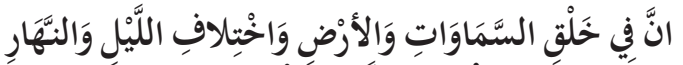

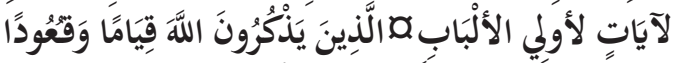

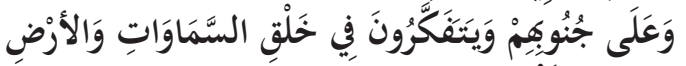

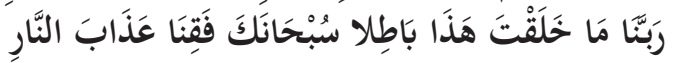
Meaning: "Behold! in the creation of the heavens and the earth, and the alternation of night and day, there are indeed Signs for men of understanding,- Men who celebrate the praises of Allah, standing, sitting, and lying down on their sides, and contemplate the (wonders of) creation in the heavens anSd the earth, (With the thought): "Our Lord! not for naught Hast Thou created (all) this! Glory to Thee! Give us salvation from the penalty of the Fire." (Q.S. 'Ali Imrān: 190-191).

The verse above explains that the laws of universe which spawned the habits, essentially defined and governed by Allah Almighty. Those essence form of an invitation people to think as proofs. ${ }^{49}$ Thus the whole creation of the heavens and the earth, as an object that is prepared by Allah to all human. And who are willing to pay attention to the creation of Allah called Ulul albab.

Ulul albab are people who have pure sense, whose mind can not be shrouded by fog ideas that can generate confusion in their thinking. They pondering about the phenomena of the universe.$^{50}$ In verse $191^{\text {th }}$ mentioned the

49 Shihab, M. Quraish. Vol. 2. Tafsir Al-Misbah: Pesan, Kesan dan Keserasian al- Qur'an. Ciputat: Lentera Hati. 2000. Pp. 290

50 Shihab, M. Quraish. Vol. 2. Tafsir Al-Misbah: Pesan, characteristics of Ulul albab, as follow: 1) Human (male or female), 2) Always remember Allah in all circumstances, 3) Keep attention to the surrounding.

Someone who has keep attention to their surrounding is similar to someone who posseses curiosity. From the explanation of the verse, the Ulul albab is likened with those people that have a high curiosity. Then, long time before the world of education has formed the cabinets, Allah has chosen candidate who will classified in the world education.

j. Nationalism

Nationalism is a strong love for your own country and the belief that it is better than any other country. ${ }^{51}$ Nasionalism derived from Latin "natio" (a nation united natural birth) objectively that nationalism is closely related to language, race, religion, civilization, region, state, and citizenship..$^{52}$

Nationalism is an understanding realized in a movement that crave a common interest, i.e. the nation interests. Nationalism implies a mental attitude, in which the supreme loyalty of the individual is for the nation state. ${ }^{53}$ The keyword of nationalism is national supreme loyalty. The loyalty arises from the awareness of different collective identity from the others. However, the most important thing in the presence of a nationalism is living and active coorperate will.

According to the scholars, nationalism is the sense of attachment (al-ashabiyah) a group of people who are in a specific geographical, who have a common goal to build an order of life system. ${ }^{54}$ Basically, nationalism was

Kesan dan Keserasian al- Qur'an. Ciputat: Lentera Hati. 2000. Pp. 291

51 Longman. LONGMAN Dictionary of Contemporary English. UK: Longman. 1978. Pp.1058

52 Moesa, Ali Maschan. Nasionalisme Kiai: Konstruksi Sosial Berbasis Agama. Yogyakarta: PT LkiS Pelangi Aksara. 2007. Pp. 28

53 Ibid.pp. 29

54 Ibid.pp. 307 
built on behalf of the plurality (al-umma), a sense of brotherhood (al qaumiyah), solidarity in diversity (asy-syu'ubiyah), equality (al musawah), and patriotism (al wathaniyah).

The national spirit has to rise in order to reinforce learner's mindset that the interests of nation and state are more important than the interests of individuals or groups. All the the rules of the Nation should be implemented as the realization of nationalism. As the word of Allah in His Book:

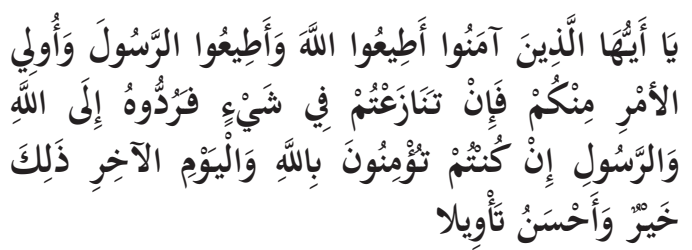

Meaning: "O ye who believe! Obey Allah, and obey the Messenger, and those charged with authority among you. If ye differ in anything among yourselves, refer it to Allah and His Messenger, if ye do believe in Allah and the Last Day: That is best, and most suitable for final determination." (Q.S. anNisā': 59).

Particularly, this verse contains the basic principles of Islamic teachings in terms of power and government. The prescribed condition to create a just and prosperous society is to obey Allah and His Messenger, to follow the ulil amr, and to make the values of the Qur'an and Sunnah as the basic law to resolve the problems (Shihab, 2000,II: 459). ${ }^{55}$

This verse commands to the believers to obey the laws of any authority decision to determine the law called "Ulil Amr". The obedience to ulil amr, is a form of participation in realization of the spirit of nationalism. Those things implemented to realize the just society, prosperous, and peaceful nation.

55 Shihab, M. Quraish. Vol. 2. Tafsir Al-Misbah: Pesan, Kesan dan Keserasian al- Qur'an. Ciputat: Lentera Hati. 2000. Pp. 459 k. Rewarding Achievement

Rewarding is something that is given in return of work, effort, ect. ${ }^{56}$ Achievement is something that you succeed in doing by your own effort. ${ }^{57}$ Then, Rewarding achievement is giving something to someone (student, child, etc.) to appreciate of what have been achieved. In Character Education curriculum, rewarding achievement define as Attitudes and actions that encourage him to produce something useful for society, and recognize the success of others.

The development of culture education and nation character can be implemented throughlessonintegration. Self development and school culture are the results of the educational process conducted by teachers and learners in the active and fun process of teaching and learning. By means of the process of learning every subject leads to develop cognitive, affective, psychomotoric and spirituality abilities.

Leadership, exemplary, hospitality, hard work, nationalism and spirit of achievement should be the school culture, especially for the teachers who should be the best figure. Proven by the teacher's behavior and classroom learning indicators are set to motivate student-learning achievement.

In His book, Allah SWT said:

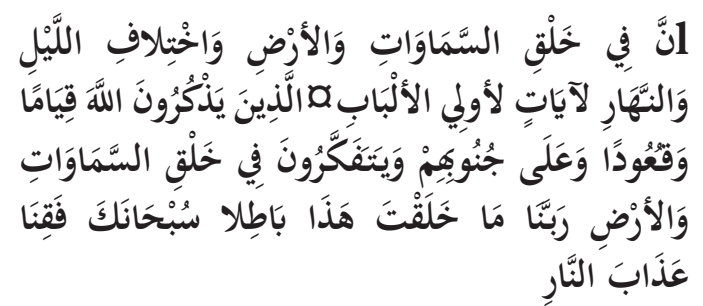

Meaning: "Behold! in the creation of the heavens and the earth, and the alternation of night and day, there are indeed Signs for men of understanding,- Men who celebrate the praises of Allah, standing, sitting, and

56 Oxford Wordpower. New York: Oxford University Press. 2006. Pp.660

57 Longman. LONGMAN Dictionary of Contemporary English. UK: Longman. 2000. Pp.13 
lying down on their sides, and contemplate the (wonders of) creation in the heavens and the earth, (With the thought): "Our Lord! not for naught Hast Thou created (all) this! Glory to Thee! Give us salvation from the penalty of the Fire." (Q.S. 'Ali Imrān: 190191).

The verse above describes the creation of universe intended as human learning objects (Shihab, 2000,II: 290).$^{58}$ Knowledge source of God has been evident from all the pleasure given to humans. The enjoyment of life in this world must be balanced with attention to their surroundings, so that life becomes helpful.

However, every individual has a different mindset. It is then explained that those who are willing to pay attention to the incidence of heaven and earth will be classified as Ulul albab "people who have a pure sense". Those who have a pure mind have a tendency to take advantage of everything surrounding, trying to find new things out that beneficial to him and others. It was by a sense of high curiosity.

Appreciating the achievements of both self and others will motivate learners to improve his achievement. This context trains students to be humble and be high solidarity personal to others. This attitude is necessary to apply in the education world to build a community that respect each other and qualified community as a nation successor.

1. Friendliness

Friendliness is behaving toward someone in a way that shows that you like them and are ready to talk to them or help them. ${ }^{59}$ There is this saying: "Good friends are like stars. You don't see them but you know they are always

58 Shihab, M. Quraish. Vol. 2. Tafsir Al-Misbah: Pesan, Kesan dan Keserasian al- Qur'an. Ciputat: Lentera Hati. 2000. Pp. 290

59 Longman. LONGMAN Dictionary of Contemporary English. UK: Longman. 2000. Pp.647 there" ${ }^{60}$ In Curriculum 2013 friendly is the Act that shows enthusiasm to talk, to mingle and to cooperate with others.

To make friend is one of the important life skills, it is equal to embed on individual socialization values. Friendship environment is an important environment after the family. So in that environment, parental controls are necessary for the child not to be affected negatively.

From several studies in this decade, friendship can accept moral values, such as; learn to care, share, and empathize. Besides that, through make a friends learned will make children gain new skills in terms of speaking ability, interpersonal skills, and the ability to control the emotions of selfishness. ${ }^{61}$

However, we need to choose and notice people who want to be friends. Because a friend will give big influence in shaping the character of individual. Yusuf and Ahmad quote from Imam Ja'far as-Sidiq in (2007: 82) explains those prohibited person to be friend are: a. People who are liars, b. Fools, c. Stingy, d. Coward, and e. The wicked. ${ }^{62}$

People need to consider though that because the Prophet Muhammad PBUH equate good friend is like a person who carries oil drawbacks and evil friend such as blower of ubupan, ${ }^{63}$ thus if we want to be a good people, we have to get along with good people too. The word of Allah SWT said:

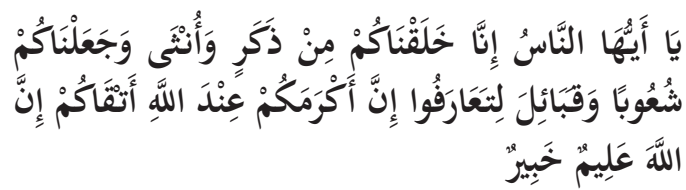
Meaning: "O mankind! We created you from a single (pair) of a male and a female, and made you into nations and tribes, that ye may know each other (not that ye

60 Mengenalkan Dunia Pertemanan. Kompas Klasika. 4 Mei, 2014. p.33

61 Ibid.

62 Ranuwijaya, Utang. Pustaka Pengetahuan Al- Qur'an. Jakarta: PT. Rehal Publika. 2007. Pp. 82

63 Ibid.pp. 80 
may despise (each other). Verily the most honoured of you in the sight of Allah is (he who is) the most righteous of you. And Allah has full knowledge and is well acquainted (with all things)." (Q.S. al-Hujurāt: 13).

The verse above describes the basic principles of public relations. ${ }^{64}$ That public relations will invite mutual symbiosis that is beneficial to all parties. Friendship is the useful form of social interaction.

Having a friend, will help obtain information from various parties, and exchange ideas about a problem. But, not everyone can give a good effect, then every student needs to have a strong fortress to counteracting bad incitement. In addition, students should be trained to be a strong faction that can put others in useful of good friendship.

m. Peace Loving

To love peace is believing strongly in peace rather than war. ${ }^{65}$ In the curriculum 2013 love peace define as attitudes, words and actions that make other people feel happy and safe over her presence.

Islam is the religion of peace, upholding the right of every member of society, promoting tolerance of other religions. The Islamic concept of Allah revealed to the Prophet is really perfect. Islam is a universal religion, completed with all the attributes to take on the modernization. ${ }^{66}$

In facing moderanization the world needs peace, we must first know the meaning of peace. Peace means not only include physical security or absence of war and conflict among us humans on earth. ${ }^{67}$ Peace is a good adjustment in

64 Shihab, M. Quraish. Vol. 15. Tafsir Al-Misbah: Pesan, Kesan dan Keserasian al- Qur'an. Ciputat: Lentera Hati. 2003. Pp. 260

65 Longman. LONGMAN Dictionary of Contemporary English. UK: Longman. 2000. Pp.1165

66 Adnan, Yahya. Islam Ajarkan Cinta Damai [online]. 2012. Available at http://www.tribunnews.com accessed 4 Agustus 2014

67 Ibid. which the parties concerned can resolve problems or disagreements by peaceful. By means of peaceful will discovery a way out which is equally harmful and create conducive atmosphere. Peace is an impulse of conscience which starts from the human mind.

Due to peace is geared in conscience, the sense of peace it must be completely embedded in the soul of every human being. Someone who has a peace-loving attitude will make people around them feel comfortable and happy.

As the word of Allah STW, below:

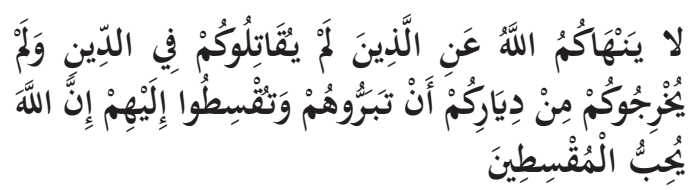

Artinya: "Allah forbids you not, with regard to those who fight you not for (your) Faith nor drive you out of your homes, from dealing kindly and justly with them: for Allah loveth those who are just." (Q.S. alMumtahanah: 8)

The verse above explains that Islam is a religion of peace. Islam is a system that aims to shelter under the banner of the Divine. ${ }^{68}$ The protection of Allah, as an example for Muslims to practice the peaceful behavior for all classes of people.

Although since the period of the Prophet have been many wars, but the law of God forbids fighting to people who do not fight us. ${ }^{69}$ From the description above, we should not attack first, if there is no attack there is no response. Then, we are taught to not reply an attack to outperform the opponent.

Even in hostile circumstances, Islam still maintains harmony with the spirit of honesty behavioral conduct, to be

68 Shihab, M. Quraish. Vol. 15. Tafsir Al-Misbah: Pesan, Kesan dan Keserasian al- Qur'an. Ciputat: Lentera Hati. 2003. Pp. 170

69 Shihab, M. Quraish. Vol. 14. Tafsir Al-Misbah: Pesan, Kesan dan Keserasian al- Qur'an. Ciputat: Lentera Hati. 2003. Pp. 169 
fair, while the opposing party accepts the offer negotiation virtue. Islam never give up in waiting for the day where the dead man became clear to establish world of peace.

If this love peace attitude has been ingrained in each individual, it will be interwoven the affection between people. Allah says:

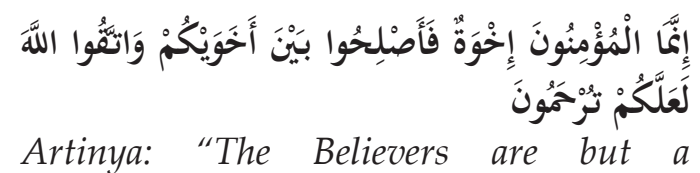
single Brotherhood: So make peace and reconciliation between your two (contending) brothers; and fear Allah, that ye may receive Mercy" (Q.S. Al-Hujurāt: 10)

The purpose of this peace love attitude is to foster a sense of brotherhood among fellow especially between faiths. By means of the affection between people it will not be easy to split and provoked by a crisis of confidence.

n. Reading Interest

Reading is the activity of looking at and understanding written word. ${ }^{70}$ Interest is a desire to learn or hear more about something or to be involved with something. ${ }^{71}$ Then, reading interest is the desire of grateful to looking at and understanding the written word. According to Suyadi reading is an activity that is capable of constructing scientific thinking. If we read various text, it will establish person's cognitive. Reading is a means to broaden and enhance knowledge.

The importance of reading is supported by the verse the Qur'an was first revealed, which is on the command to read "iqra ". As stated in the surah of al-'Alaq:

70 Longman. LONGMAN Dictionary of Contemporary English. UK: Longman. 2000. Pp.1312

71 Oxford Wordpower. New York: Oxford University Press. 2006. Pp.416

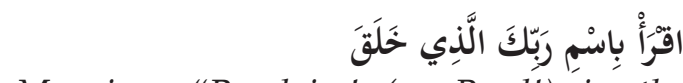

Meaning: "Proclaim! (or Read!) in the name of thy Lord and Cherisher," (Q.S. al'Alaq: 1).

From these verses, we know that the command read already should inherent in every individual, because it is the Lord's commands to humans.

Reading will be able to help character building of the individual, because the reading is not only to obtain information, but also to understand, and learn to choose intelligently and selectively in critically reading activities. ${ }^{72}$ Critical reader will form his own personality in daily life. They would become sturdy founding members of the community, not easily provoked, can control self, critical thinking, and always carefully assess the truth of each event encountered.

The benefits of reading above, has the same vision to be achieved in the implementation of curriculum 2013. That establish sturdy personality generation and have a critical spirit in every instance by taking lessons from each events happened.

o. Social Concern

Social is concerning the relation between people or groups of people, relating to the organization of society. ${ }^{73}$ Concern is give attention to something. ${ }^{74}$ Then, social concern is interest feeling concerning the relation of people relating the organization of society. In the character education curriculum, social caring define as an attitudes and actions always want to help to others and communities in need.

Essentially, humans are social creatures who can never live alone. Then the social environmental factors

72 Suyadi. Mencegah Bahaya Penyalahgunaan Narkoba Melalui Pendidikan Budaya dan Karakter Bangsa. Yogyakarta: ANDI. 2013. Pp. 89

73 Oxford Wordpower. New York: Oxford University Press. 2006. Pp.735

74 Ibid.pp. 157 
are very important in their survival. Immediate environment is influential in determining the level of social awareness. Those environment are; family, friends, and environments community.

Social environment undertaken by a person will affect its personality and character in certain form, whether it is meaningful, or material. ${ }^{75}$ If the individual's social environment teaches good social values, then individual's social caring would be formed properly.

Sense of the social care should be cultivated, in order to realize human essence that according to Aristotle called zoon politicon which is predetermined to live in a society and interact each other. The aim of social caring is to relieve distress or difficulties of others in facilitated in every difficulty.

Help others who are having trouble is the realization of solidarity. The concern is not based on sense of self-interest, but because they feel that helping other people is the duty of every human being. As explained on the unity of the believers in following God's word:

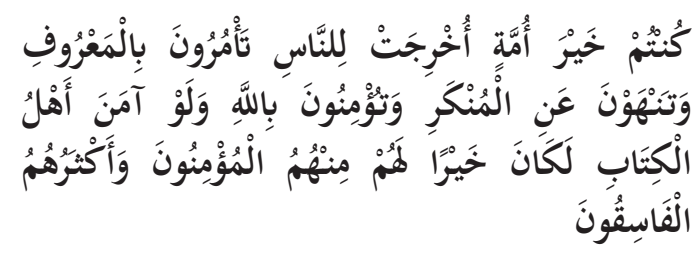

Meaning: "Ye are the best of peoples, evolved for mankind, enjoining what is right, forbidding what is wrong, and believing in Allah.434 If only the People of the Book had faith, it were best for them: among them are some who have faith, but most of them are perverted transgressors" (Q.S. Ali Imran: 110).

The verse describes the good people, which in the context of human sociology is the set of all its members together

75 Murshafi, Muhammad Ali. Mendidik Anak agar Cerdas dan Berbakti. Surakarta: Ziyad Visi Media. 2009. Pp.56 towards the same direction, help each other, and dynamically moving under the leadership. ${ }^{76}$ So the good people in the life of the community is that who help each other, share a common vision for the mutual benefit of people and caring social environment.

To establish good character of individual, it starting from the environmental community's social life. Good people were explained in verse represent people who has the soul of social caring.

p. Environmental Concern

Environment is all the situation, events, people etc. that influence the way in which people live or work. ${ }^{77}$ Concern is give attention to something. ${ }^{78}$ Environmental concern is give attention to the environment. In Curriculum 2013, environmental concern is an action to prevent damage in the surrounding environment, and develop to measures the occurred damage.

Environmental concerns declared general attitudes of willingness to declared the actions that can improve and maintain the quality of the environment. The awareness on environmental issues needs to be empowered to avoid damage of natural resources. It will maintain the viability of the earth. If we are able to preserve the environment, then we have given respect for nature.

The essence nature appreciation is the awareness that human being is part of nature. Then, loving the nature is loving the human life. Loving environment direct the loving life attitude. When, everybody loves the environment and nature, then everyone

76 Shihab, M. Quraish. Vol. 2. Tafsir Al- Misbah: Pesan, Kesan dan Keserasian alQur'an. Ciputat: Lentera Hati. 2000. Pp. 174

77 Longman. LONGMAN Dictionary of Contemporary English. UK: Longman. 2000. Pp.533

78 Oxford Wordpower. New York: Oxford University Press. 2006. Pp.157 
will care to maintain the viability of the environment. Never destroy and exploit the environment, to create an environment that benefits for all humans as part of the environment.

In His book, Allah said:

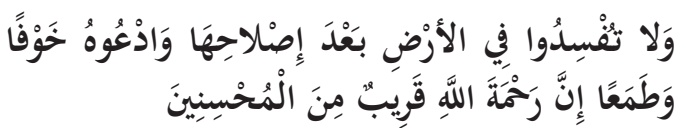

Meaning: "Do no mischief on the earth, after it hath been set in order, but call on Him with fear and longing (in your hearts): for the Mercy of Allah is (always) near to those who do good" (Q.S. al-A'rāf: 56)

The verse above contains the prohibition of Allah to not do mischief on earth. ${ }^{79}$ Do not perform the damage on earth that can be realized with environmental concern. Environmental concerns will lead individuals to be cautious in acting and trying to preserve the environment.

The application of environmental concern is deemed necessary attitude instilled in students in order to build an intellectual community that modern spirit and care about the environment. Toward the era of modern technology, educational institutions was important to share in protecting the environment to not lose by the development of era. Then the realization form is to establish the agent of change to leads the creation of go green.

q. Responsibility

Responsibility is an ability to behave sensibly and make good judgment in a way that shows you can be thirsted. ${ }^{80}$ In the 2013 curriculum, the responsibility means the human's attitude to be responsible to do his duties that should do toward his self, society and environment (nature, social and culture), nation and God

79 Al- Maraghi, Ahmad Mustofa. Tafsir Al- Maraghi. Semarang: CV. Toha Putra. 1974. Pp. 314

80 Longman. LONGMAN Dictionary of Contemporary English. UK: Longman. 2000. Pp.1350
The responsibility is a noble attitude and it had become basic human's attitude that can be called as natural tendency (fitrah). However, this attitude can be moved by the external factor. It is everybody attitude and it will be better when his personal is better. This attitude is always being a basic human's attitude because they have been a part of society who can't detach their self from the social life. This condition makes the responsible frequency of each people is different.

The responsible attitude is human characteristic as a noble people. Human be liable because they know their good or bad action and aware that the other needs their subservience. ${ }^{81}$ People can be responsible humans through education, information, model and piety (takwa) to God. Thus, the responsible attitude has many kinds that everyone should complete it.

In the Islamic discourse, responsibility means the individual responsibility. A Muslim will not load the responsible of others. Allah said:

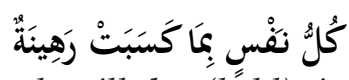

Meaning: "Every soul will be (held) in pledge for its deeds." (Q.S. al-Muddaśśir: 38).

That verse explains about human those are pawned by Allah and they have to do charity. ${ }^{82}$ That verse also describes the lesson of responsibility attitude that means human should be responsible to pay their selves as Allah pawning. The meaning sense of this is to learn human in order to thank God for his blessing.

The responsible attitude will show and educate person to have big

81 Damayanti, Ika. Manusia dan Tanggung Jawab serta Pengabdian. Available at www.academia.edu . accessed 8 Agustus 2014 at 20.52

82 Shihab, M. Quraish. Vol. 14. Tafsir Al-Misbah: Pesan, Kesan dan Keserasian al- Qur'an. Ciputat: Lentera Hati. 2003. Pp. 606 
curiosity within the positive response toward him or others. Someone who has responsibility will be more careful on his actions, carrying out the task based on trustee (amanah) and discipline on the rule and can lead himself because all sides of life need responsibility.

\section{CONCLUSION}

Based on the discussions and analyzes in previous chapters, it can be concluded that as is guidance book for Muslims, AlQur'ān contains the source of all knowledge, instructions and inspiration of truth that nothing ever runs out. Qur'an invites all believers to be religious, honest, tolerant, discipline, hard work, creative, democratic, curious sense, the spirit of nationality, loving the country, rewarding achievement, friendly, peace loving, reading interest, social concern, environmental concern and responsibility. All of the content is referring to the value of $18^{\text {th }}$ character values curriculum in 2013. By means of those statements, means that character education in Qur'anic verses has relevance with character education in curriculum 2013. The emergence of this curriculum was caused by moral degradation of student and society. The aim of this curriculum is to establish the personality to be a good man, and a good citizen. This aim is in accordance with the purpose of Al-Qur'an as guidance for Muslim so that they can be good people in front of their God and other people. Wallahu 'alam

\section{BIBLIOGRAPHY}

Adnan, Yahya. 2012. Islam Ajarkan Cinta Damai [online]. Available at http://www.tribunnews. com accessed 4 Agustus 2014

Afandi, Rifki. 2011. Integrasi Pendidikan Karakter dalam Pembelajaran IPS di Sekolah. Pedagogia vol. 1, No. 1, Desember 2011. Pp. 85-98

Al- Maraghi, Ahmad Mustofa. 1974. Tafsir Al-Maraghi. Semarang: CV. Toha Putra

Asmani, Jamal Ma'mur. 2011. Buku Panduan Internalisasi Pendidikan Karakter di Sekolah .Yogyakarta : DIVA Press

Damayanti, Ika. Manusia dan Tanggung Jawab serta Pengabdian. Available at www.academia. edu . accessed 8 Agustus 2014 at 20.52

Encyclopedia International Vol. 6. 1973. New York: Grolier Incorporated

Hornby, A.S. 1974. Oxford Advanced Learner's Dictionary Of Current English. Oxford: Oxford University Press

Koesoema, Doni. 2012. Pendidikan Karakter: Untuh dan Menyeluruh. Yogyakarta: Kanisius

Latumahina, Donald. 4 Reasons Why Curiosity is Important and How to Develop It [online]. Available at (http://www.lifehack.org) accessed 6 Agustus 2014 at 10.56

Listyarti, Retno. 2012. Pendidikan Karakter: dalam Metode Aktif, Inovatif, E Kreatif. Yogyakarta: Erlangga Group

Longman. 1978. LONGMAN Dictionary of Contemporary English. UK: Longman.

Mengenalkan Dunia Pertemanan. Kompas Klasika. 4 Mei, 2014. p.33

Moesa, Ali Maschan. 2007. Nasionalisme Kiai: Konstruksi Sosial Berbasis Agama. Yogyakarta: PT LkiS Pelangi Aksara

Munir, Abdullah. 2010. PENDIDIKAN KARAKTER: Membangun Karakter Anak Sejak dari Rumah. Yogjakarta: PT. Bintang Pustaka Abadi

Murshafi, Muhammad Ali. 2009. Mendidik Anak agar Cerdas dan Berbakti. Surakarta: Ziyad 
PROFETIKA, Jurnal Studi Islam, Vol. 17, No. 2, Desember 2016: 93-112

Visi Media

Muslich, Masnur. 2011. PENDIDIKAN KARAKTER: Menjawab Tantangan Krisis Multidimensional. Jakarta: Bumi Aksara

Mustaqim, Abdul. 2005. Menjadi Orang tua Bijak: Solusi Kreatif Menangani Berbagai Masalah Pada Anak. Bandung: Mizan Media Utama (MMU)

Natsir, Haedar. 1997. Agama dan Krisis Kemanusiaan Modern. Yogyakarta: Pustaka Pelajar

Oxford Wordpower. 2006. New York: Oxford University Press

Sahlan, Asmaun. 2009. Mewujudkan Budaya Religius di Sekolah: Upaya Mengembangkan PAI dari Teori ke Aksi. Malang: UIN- Maliki Press

Shihab, M. Quraish Vol.1-15. 2000. Tafsir Al- Misbah: Pesan, Kesan dan Keserasian al- Qur'an. Ciputat: Lentera Hati

Suhartono, Suparlan. 2008. Wawasan Pendidikan. Jogjakarta: Ar-Ruzz Media

Sukiyat. Tth. Pendidikan Karakter: Dasar Membangun Moral Bangsa [online]. Available at www. slideshare.com accessed 4 Februari 2014 at 11.28

Suwarno, Wiji. 2006. Dasar-Dasar Ilmu Pendidikan. Jogjakarta: AR-RUZZ

Suyadi. 2013. Mencegah Bahaya Penyalahgunaan Narkoba Melalui Pendidikan Budaya dan Karakter Bangsa. Yogyakarta: ANDI

Syafri, Ulil Amri. 2012. Pendidikan Berbasis al- Qur'an. Jakarta: Raja Grafindo Persada.

Syahroni. Tth. Konsep Pendidikan Karakter. PDF [online]. Available at http://lampung. kemenag.go.id accessed February $4^{\text {th }} 2014$ at 11.20

Tantangan Pembentukan Karakter Siswa Indonesia [online]. Available at http:// pendidikankarakter.org diakses pada tgl 1 November 2013 pukul 06.57

Wahid, Abdurrahman. 2010. Dialog Pearadaban untuk Toleransi dan Perdamaian. Jakarta: PT Gramedia Pustaka Utama.

Widodo, Syukri Fathudin Achmad. Tanpa tahun. Pendidikan Karakter dan Implementasinya. Pdf. Universitas Negeri Yogyakarta diakses pada tanggal 1 November 2013 pukul 07.09

Pentingnya Menanamkan Nilai Kejujuran pada Anak. 2012. Available at www. nilaikejujurananakk.blogspot.com 